\title{
Opening Up to Hard History: Activating Anti-Racism in an Immersive Ed.D. Cohort Experience at Heritage Sites in Montgomery, Alabama
}

\author{
Theresa G. Coble \\ University of Missour - St. Louis \\ coblet@umsl.edu \\ Corinne Wohlford Mason \\ Fontbonne University \\ cmason@fontbonne.edu \\ Lisa Overholser \\ University of Missouri Extension \\ overholserl@missouri.edu \\ William W. Gwaltney \\ National Park Service (Retired) \\ gwaltney479@yahoo.com
}

\begin{abstract}
The Ed.D. program in Heritage Leadership for Sustainability, Social Justice, and Participatory Culture at the University of Missouri-St. Louis helps students cultivate the mindsets and skill sets required to sustain, pluralize, and enliven heritage in the public sphere. Although the program primarily meets synchronously online, the January 2020 "Wintercession" field trip to heritage sites in Montgomery, Alabama, provided an opportunity for face-to-face interactions, deep conversation, and reflection. Curricular, conversational, and collaborative inquiry deepened awareness and activated activism toward issues of racial justice. The use of high-impact practices (Kuh, 2008) allowed the cohort and faculty mentors to delve further into heritage leadership themes, including: confronting difficult emotions, recognizing sanctified space, facilitating group bonding and trust building, identifying models for activism, and moving forward in activism. We argue that the emergence of these themes demonstrates the value of immersing students and faculty in a shared, high-impact experience that focused on awareness, remembering, and wondering - the process of imagining the not yet (Keenan-Lechel et al., 2019) —as a means to "activate activism" in a cohort-based Ed.D. program.

KEYWORDS: memorials, affect, contested space, high-impact practices, activism, equal justice initiative
\end{abstract}

Under stress, an unexercised heart will explode in frustration or fury. If the situation is especially tense, that exploding heart may be hurled like a fragment grenade toward the source of its pain. But a heart that has been consistently exercised through conscious engagement with suffering is more likely to break open instead of apart. Such a heart has learned how to flex to hold tension in a way that expands its capacity for both suffering and joy. (Palmer, 2011, p. 60)

In August 2019, the University of Missouri-St. Louis (UMSL) admitted its second cohort of 26 doctoral students who will focus their Ed.D. inquiry on Heritage Leadership for Sustainability, Social Justice and Participatory Culture. We view heritage as a contested and contextualized phenomenon tied to collective memory, identity, and creativity. For our purposes, heritage leadership cultivates the mindsets and skill sets required to sustain, pluralize, and enliven heritage in the public sphere. Vlad Glăveanu, a Swiss scholar of creativity, culture, and the arts, views creativity as an emergent property of experiences that open people up to difference and to the perspectives of others. He maintains that creativity is embedded within a given representational space, but as individuals communicate and as collaboration unfolds, a common representational space emerges "where cultural norms and systems of thought are played with-where representational elements turn into symbolic resources" (Keenan-Lechel et al., 2019, p. 653). Building and sustaining a common representational space requires group members to engage in dialogue, hold tension, and operate within a context of risk and uncertainty. But the benefits outweigh the risks because enriching the common representational space also enriches the personal representational space of each participant (Keenan-Lechel et al.). When participants "open up rather than close
New articles in this journal are licensed under a Creative Commons Attribution 4.0 United States License.

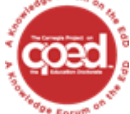

This journal is supported by the Carnegie Project on the Education Doctorate: A Knowledge Forum on the EdD (CPED) cpedinitiative.org 
history" (Caruthers, 2007, p. 311)—grieving difficult history, wrestling with the aftermaths, and engaging otherness--they sketch the contours of an emotional geography (Askins \& Swanson, 2019). In doing so, factors like emotions, empathy, and trust must be in play (Keenan-Lechel et al.).

As heritage leadership faculty mentors, we are keenly aware of the need to cultivate emotional engagement, empathy, and trust. Thus, we established norms of collaboration (Garmston \& Wellman, 2013) via weekly class meetings, using Zoom so we can see and hear each other. We rotate leadership responsibilities, bringing student voice and thought leadership to the fore. Our three-year heritage leadership curriculum begins with TED talks and texts that showcase the challenges and some of the solutions to achieving sustainability, social justice, and participatory culture (e.g., Alexander, 2012; Bales, 2016; Hawken, 2017; Liu, 2017; Palmer, 2011; Rothstein, 2014; Wallace-Wells, 2019). As an online program, our Wintercession week is the only time in the calendar year set aside for immersive experiences, face-to-face interactions, and team building. It is our time to pursue transformative praxis, nurture wholeheartedness, and hold tension. This helps us embrace the discomfort, rather than swiftly diverting our gaze or succumbing to easy answers as we confront difficult issues (Burbules, 2016; Sibbett, 2016). We feel there is no substitute for immersive, placebased experiences in which, "history and consciousness duel anew" (Kendi, 2019, p. 33), so we planned a four-day field trip to Montgomery, Alabama, as a highlight of our time together.

\section{CURRICULAR METHODS TO DEEPEN AWARENESS, ADD NUANCE, AND ACTIVATE ACTIVISM}

Heritage leadership Ed.D. students traveled by caravan in five vehicles from Saint Louis to Montgomery on Thursday, January 16, 2020. Because the program runs primarily online, the nearly ninehour drive was the first time that the students spent an extended period of time together. A component of our Wintercession course, the trip included 26 students (10 black, 16 white) and seven faculty mentors (two black, five white-one of whom was of Arab descent). On Friday morning, the group met for a discussion of two pieces related to race and pedagogy: Matthew R. Kay's (2018) Not Light but Fire: How to Lead Meaningful Race Conversations in the Classroom, and Smith and colleagues' (2017) exploration of the challenges white professors encounter when they teach about racism. Shortly thereafter, the group walked to the Legacy Museum, which they explored on their own. At the Legacy Museum, students had an opportunity to visualize the past, to be caught short by an image or artifact, to engage with the experiences of perpetrators and victims, and to reflect on the justifications that allowed such dehumanization to persist. Perhaps most importantly, they considered how this diminishment challenges us today. At one point, our Ed.D. students turned a corner and encountered these words: The formal abolition of slavery did nothing to overcome the harmful ideas created to defend it, and so slavery did not end: it evolved.

After lunch, we proceeded to a question and answer session with Kayla Vinson, a lawyer from the Equal Justice Initiative, who spoke broadly about the organization's efforts in and outside Montgomery. Finally, the students and faculty mentors visited the National Memorial for Peace and Justice ("the lynching memorial," as our group called it), exploring it in small groups and as individuals. The next day, the schedule was identical, allowing students to return to the sites that they had visited previously for deeper reflection and contemplation. Additionally, many students stopped at the Legacy Pavilion, which opened to the public for the first time that day, for a soul food lunch or to browse the extensive bookstore. Others made time to visit the Dexter Street Baptist Church, Rosa Parks commemorative sites, and/or the Freedom Riders Museum during walks, runs, or other downtime. The return ride on Sunday was a chance to discuss the deep feelings and concerns that the sites had stirred in them.

Students were tasked with three projects during their time in Montgomery. The first was a six-minute video of their experiences, to be narrated with commentary. The video was intended to elicit insight related to their personal experiences. Students also wrote a lengthy written reflection and created a facilitated dialogue action plan focusing on some aspect of racial justice. We held dialogue sessions before and during the field trip and provided students with materials prepared by the National Park Service in conjunction with the International Coalition of Sites of Conscience and the Tenement Museum (see for example,

https://www.nps.gov/orgs/1244/upload/About-Allies-for-InclusionDialogues_2015.pdf). The heritage leadership Wintercession concluded at UMSL with a Martin Luther King, Jr. observance that featured Dr. Marc Lamont Hill (Temple University) and Brian Owens (LIFE Arts, Inc.).

The authors reviewed all student-produced artifacts as well as the transcript of our subsequent online in-class discussion of the trip in order to produce a thematic analysis of this high-impact experience, drawing from our own diverse academic backgrounds. Our combined academic backgrounds include history, American studies, music, folklore, forestry, and Chinese; our professional backgrounds include service in the National Park Service, museums, and battle sites; community engagement programming; and work in higher education as faculty and administrators in the social sciences and humanities. Three of us identify as white women, one as an African-American man. We paid special attention to the differing responses of white and black students--in particular, how they approached the museum and memorial and related the difficult histories to their own experiences.

This learning experience represented an engagement with what Alderman and associates (2020) term "affective heritage," in that students focused largely on feeling and emotion, encouraging student resolve toward activism in their emerging careers as heritage leadership professionals. Montgomery itself, which describes itself as the birthplace of both the Confederacy and the Civil Rights movement, and the museum and memorial in particular, served as "wounded places" (Alderman et al., 2020) with which the students reckoned with the histories of racism and capitalism in the spectacle of the lynched body in history and the contemporary reality of mass incarceration and injustice in the prison system. Students grappled deeply though divergently with what they encountered, as might be expected in any sort of field experience; however, the woundedness of these sites and their divergent cultural meanings seemed to produce particularly profound affective engagement.

The five themes we identified were the following: confronting difficult emotions, recognizing sanctified space, facilitating group bonding and trust building, identifying models for activism, and moving forward in activism. We argue that the emergence of these themes demonstrates the value of immersing students and faculty in a shared, high-impact experience that focused on awareness, remembering, and wondering - the process of imagining the not yet 
(Keenan-Lechel et al., 2019) as a means to "activate activism" in a cohort-based Ed.D. program.

\section{CONFRONTING DIFFICULT EMOTIONS}

Student responses emphasized their trepidation about the trip even before they left Saint Louis; these responses were especially prominent amongst white students. Several expressed what one student called "low expectations" of the trip; another described being "extremely hesitant." Another wondered why faculty would take the students to Alabama to explore racial injustice when Saint Louis abounds in its own race problems. On a more basic level, many expressed a concern about being in a vehicle with near-strangers for an extended period of time and/or to leaving family or work obligations behind. A white woman wrote that she worried about "wanting to fit in, wanting to mesh," in order to "have a good road trip." Even more, however, focused on what they correctly anticipated would be an intensely emotional experience. The trip was "completely outside my comfort zone," wrote one white woman; two other white women described themselves as "nervous" and another as "insecur[e]" about engaging with the difficult racial topics. As they began to feel powerful emotions from the sites, some white students questioned their right to be there at all. "I keep asking myself if I should be at the Legacy Museum. In essence, what do I have to cry about?," wrote one. Another asked, "What the hell am I doing?" Many reported tears.

Black students expressed considerably less trepidation about the trip's emotional content, with many stressing that the content of the museum and memorial was "not new." One of the black men, for instance, described the trip's value as "not necessarily the information but the experience." A black woman noted she was "already versed in my history." However, some black students, like their white colleagues, expressed stress, annoyance, or anxiety about the trip in general, for similar work and family reasons. One noted that she felt more comfortable early in the trip sticking with other black students, and another remarked, without subsequent detail, "barriers of race" in the group.

It is important to note that black students may have had reason to moderate their expressions of discomfort, especially as it related to white student responses, in order to promote group harmony-as student responses were visible to one another-or to avoid any perceived potential offense to the faculty team. We believe it is eminently reasonable for our black students to have concerns about traveling in an interracial group to a site of such intensely violent racist history. However, one black student observed that all "[p]articipants were vulnerable and courageous enough to lean to places of discomfort," and others eventually expressed appreciation for sharing the trip with white classmates. While most hotel roommate accommodations were single-race, every van was notably a mixture of black and white students and/or faculty mentors.

\section{RECOGNIZING SANCTIFIED SPACE}

For many students, the sites in Montgomery went beyond purposes of education or information, even if they did encounter "new" information. The Legacy Museum's location on the site of a slave warehouse imbued the space with an absent presence that haunted its atmosphere. Even more powerfully, the lynching memorial represented a sanctified space in which students could engage in "quiet contemplation." One black student described a feeling of peace at the memorial, where she said it felt as though "the heavens had opened." The sense of reverence in the lynching memorial caused students to feel they needed to whisper, if they spoke at all. In her video, D, a black woman, filmed images from the memorial without commentary, simply imploring the viewer to "breathe," creating an act of meditation in the video itself; at another point, she implores, "Lord, have mercy." In a similar vein, a white classmate described himself as "moved to a place of speechlessness." Another white male student described feeling "haunted" at the memorial: "As I navigated the space, I couldn't help but wonder what [the lynching victims] might be thinking of me....In being here, in doing my best to be fully present, I was haunted by the legacy of their stories.... even imagined what it would be like if the crushing weight of their history came down on me, physically, as I navigated the memorial." Describing the holograms of enslaved men and women that speak to visitors at the Legacy Museum, one white student felt confronted in her white privilege as a "ghost literally looked me in the eye." Others of both races described the emotional resonance of standing in the church where Dr. Martin Luther King preached, on the footsteps placed in the crosswalk near the Alabama state capital in commemoration of the Selma-Montgomery march, and of standing where Rosa Parks famously boarded the bus and-a short distance away-was arrested. It was powerful to stand "where history was made," wrote one. Another eloquently described the trip as "horrifically beautiful."

These responses indicate that the students experienced several sites in Montgomery as sanctified spaces. The "absent presence" of the victims of slavery and lynching and of Civil Rights icons imbued these places with meanings that could not be simply categorized or described. The students participated in collective memory work that connected their own identities to those of the past. Responses that emphasized sanctity often were the most personal and eloquent; however, they typically did not engender critique. They were embodied physically in images, sounds, breath, prayer, tears, and even silence. Although many engaged in conversation with site staff or with one another, the lynching memorial, in particular, functioned as a collective site of mourning and reflection. As one student wrote, at the lynching memorial, "here I could only mourn."

\section{FACILITATING GROUP BONDING AND TRUST BUILDING}

The shared experience of grief and growth resulted in significant connections between students. In class after our return, we asked students about how the experience had differed for them because they traveled with the Ed.D. program cohort rather than alone or with family or friends. Students noted that even the van rides, which in some cases had been dreaded, had been a valuable chance to converse with classmates and faculty team. Of particular interest was an emphasis in their comments on the spontaneous and unscripted nature of exchanges in the vans, which ranged from playful singing of songs together to serious discussion. Several contrasted the open discussion in this setting with the more formal online classroom environment, in which students already have some sense of what they will be discussing each week and can formulate thoughts and responses in advance-for instance, the student who noted that conversations on the trip were "organic and not forced." The presence was one of "brotherly/sisterly" relationship, wrote one student. "Being in a van for nine hours with people you don't know 
demands learning," wrote one student; another concurred that "social time is so important when cultivating a working group." Content aside, the experience of the van rides proved valuable to building community across the cohort that will be important as they work together over the next three years.

One faculty mentor concern was for the emotional labor of the black students on this trip. In Montgomery, one black female student, $\mathrm{J}$, repeatedly mentioned not wanting to serve as a "case study" for white students, as though white students would be monitoring her for a response. Others concurred: "Sometimes you feel like a spectacle... it can be exhausting!" However, J also wrote eloquently about experiences that pushed her in a positive direction. She shared that at one point during a visit to the Legacy Museum, she met eyes with a white woman-not a member of the cohort-who had been crying and looked "apologetically" at her. The student admitted that "on our first day of exploration," she had felt some "curiosity or even judgment" about how her white peers were responding to the sites; however, when she saw the white woman's pain at the site, J reflected, "This was poetic for me because I do hold some personal biases and opinions about 'they,' but her compassion chipped away at my resolve." She continued that witnessing " 26 of us with our hypothetical shovels digging to unpack the answers and remedies needed to mend our country and heal our world" shifted her perspective somewhat. "This was an experience unlike any other I have had," J wrote. In class discussion, she remarked, "Being part of the group forced [me] to not be so selfish or one-sided in my thinking." Another black woman remarked, "I felt a sense of responsibility for those with me, meaning how they were feeling, processing. We supported one another through the various intervals of our feelings...Even though we all had our own personal experiences, there was always a sense of togetherness." Another black student reported that despite her normally introverted nature, the group made her speak up more and to "realize that this period doesn't just negatively [a]ffect African Americans."

Although we are aware that some more candid feelings may not have been expressed in written or recorded responses, in most cases, the black students valued being in an interracial group, allowing for a greater diversity of perspectives on information that, for most black students, was already familiar. Several white students also remarked on what they gained from their black classmates. One white student described being overwhelmed with emotion at a video in the Legacy Museum, and a spontaneous hug from a black peer at that moment surprised and heartened her. Another appreciatively described how two of his black classmates encouraged him to lean into his fears and grapple meaningfully with what was found there. After speaking with a black classmate, a white student said "I know that I felt my whiteness more than I ever had before."

White students described pushing past their initial difficult feelings. One white woman reflected in class, "I felt like as a group even though we are all like-minded in that we are growing towards being heritage leaders, I think the group was large enough to have a broader representation of ideas and experiences which helped add value to the places." Another appreciated that the group had been helpful because "we weren't experiencing it alone." One reflected, "It seemed as though we could handle more complex discussion, share diverse perspectives, and pool our collective knowledge because there were so many of us." One remarked that "having a mixed-race group that had created at least somewhat of a safe space opened the conversation and allowed me to be more vulnerable with topics such as white people leading race conversations or white guilt."
Some students also remarked upon the professionalizing experience of traveling to the sites as part of an Ed.D. cohort. "I sensed my responsibility more than a tourist type of experience," wrote one white student; another, black, shared that she felt she was "mining the museum" in a "new light" as she engaged a "tourist location with a learning hat." The collaborative opportunity increased professional resolve for the group. The group's professional commitments mean that they were "trying to understand our place as heritage leaders." A black student who repeatedly stressed the professionalizing elements of the trip pushed back slightly on the idea of black students being case studies, asserting that to become a heritage leader is to become a case study. "[A]nd to that end," she remarked, "I'm willing to be vulnerable and open."

Although the group experience seems to have been effective for all students who responded and commented on it, several also remarked on the need for their own down time to reflect alone, as well. The intensity of the experience was exhausting for many, even when the shared experience was of value. One student remarked that, when she returned to UMSL on Monday for Martin Luther King, Jr. Day services, the speaker had remarked that to some extent, one would always be alone in the pursuit of racial justice. Here was one point, she said, where she disagreed, because in her cohort, pursuing racial justice, she did not feel alone anymore.

\section{IDENTIFYING MODELS FOR ACTIVISM}

We were struck by the ways in which the students sought connections with people outside the group, even during a short stay. By far the most influential person the students met was Kuntrell Jackson, a volunteer at The Equal Justice Initiative. Jackson had been incarcerated for life, without parole, at age 14 in Arkansas. Jackson had stayed outside when two friends entered a video store, intending to rob it, and instead killed the clerk. With the advocacy of The Equal Justice Initiative, Jackson was released from prison in 2013 and today engages with visitors to share his story. Students connected with Jackson's story and his commitment to education and activism today. Some shared lunch with him; others invited him to Saint Louis to speak. One student, a white male police officer, apologized to Jackson on behalf of the criminal justice system, a gesture that touched many others in the cohort.

Jackson provided extensive emotional labor to studentssharing his difficult story, his faith, his hope, and his humor while they listened, many of them filming him as he spoke. Students were deeply grateful for Jackson's candor, though we did not hear any students directly express a concern for the emotional work that Jackson's sharing must have represented. As Munro (2014) has suggested, such sharing of oneself via community engagement can be very draining. Although one student privately expressed one of us some discomfort with engaging with Jackson as though he were a performer, many seemed to interpret Jackson himself as an embodied version of the wounded place, redeemed through the work of the Equal Justice Initiative and his own courage and will to reform his life.

In addition to Jackson, students drew inspiration from other leaders and models of activism. Several mentioned the Equal Justice Initiative lawyers and staff on hand at both the museum and memorial who answered questions about their experiences at the sites. Three students made serendipitous connections with heritage leaders at other Montgomery sites. Wanda Battle, tour director at the Dexter Avenue Baptist Church, wowed one student with her ability to 
build community, share history of both national and personal scale, and challenge visitors to the sanctuary where King once preached. Another pair of students met Dorothy Walker, site director of the Freedom Riders museum, which had just closed when they approached the building. Walker stopped to talk with them at length about their visit and research interests, offering them literature to distribute to the rest of the cohort and future remote assistance. Students reflected on the ways these leaders differently engaged with Montgomery's past, advocating through their particular stories and the stories of the place. However, it was not only official sources from which students drew inspiration. Others mentioned meaningful connections and learning from bus drivers and hotel staff who did their part to share Montgomery's history. One student remarked on letters displayed at the museum written by incarcerated men and women as a piece of activism toward which she felt "a responsibility to respond." Another student noted that simply the presence of signs around Montgomery that commemorate Civil Rights and slavery were important signs of activism and acknowledgment, an observation in alignment with Cook's (2018) study of Alabama's historical markers.

Wahl (2019) argued that a better understanding of racial oppression could prompt one to (re)consider the appropriateness of adversarial actions like confrontation and protests. We also discussed with students the value of museums and memorials as activist spaces. This point seemed especially salient in that so much of the experience in Montgomery focused on feelings of woundedness and grief. Many expressed that "the work of acknowledgment...is a first step" in activism. Another remarked on the need for education through sites like these to "move forward."

\section{MOVING FORWARD IN ACTIVISM}

Izard (2010) highlights key functions of emotions that are relevant to our visit to Montgomery-namely, emotions motivate and organize cognition and action. Emotions provide information to us about our experiences. Emotions may integrate our antecedent cognitive appraisals and influence our ongoing cognition. They may motivate our approach or even cause avoidant behavior. And in a non-trivial way, emotions may be social or relational in nature.

It was the in-working and out-working of emotion that prompted many students to leave Montgomery with a renewed sense of commitment to racial justice. "I can assure you," wrote one, "that my life was altered by this trip." Another wrote, referring to Kay's Not Light but Fire text, "I damn well know I am going to make fire where others have shed light." Some had specific and concrete ideas to implement-for instance, a new way to lead a book club discussion. Others had a renewed commitment to issues such as the school to prison pipeline. Another who considered herself "an advocate for sexual assault victims" reflected on the ways that white men had "used sexual assault as a validation for murder" and connected this realization meaningfully to her advocacy work. One white woman in particular focused on moving from feelings of "white guilt to white responsibility." Another hoped to volunteer in voter registration efforts. A language arts teacher in a predominantly white school district reflected on how she would build a course on black literature, already in progress. A police officer hoped to bring these insights into his career in law enforcement.

Many students expressed a particular concern about history education: where, they wondered, had information about slavery, lynching, and incarceration been in their curricula, whether as students or educators? For the one student who is a high school history teacher, application of this material was most direct: "I think I will be able to teach a much better American History class first and foremost." Although student calls for teaching "true history" were somewhat problematic from a disciplinary perspective, the resolve to educate formally and informally on slavery, lynching, and mass incarceration were strong. One remarked that "ultimately this dialogue serves as a navigational tool" for future discussions. "A lot of people are moving through life with false ideas," wrote another, emphasizing the need to be optimistic and yet to share "the untold story." Many reflected on ways that they were sharing newly learned information with family, colleagues, and almost anyone who would listen since they had returned. Students agreed, however, that they were "not striving to be Rosa Parks," as one student commented; rather, they wanted to use their professional platforms to advocate better in the areas in which they have influence. In these discussions, many students pivoted to their graduate education as an important platform for making change.

However, exactly how these strong feelings and renewed commitments would manifest was still diffuse. One white student described a discussion with a black peer, in which they agreed that "the last thing we need with respect to race relations is a whole new set of 'fixes."' Our review of the students' facilitated action dialogue plans suggested the wisdom of this comment. We had asked students to prepare a dialogue based on some aspect of racial justice, to be implemented at some specific future time and place. With the short Wintercession format of the course, we realize in retrospect that this assignment asked students to pivot too soon from sanctified grief into concrete action steps. While all the students suggested interesting discussion topics, most of them focusing on education-related topics, the responses were generally not interpretive, were overly broad and vague, and were not ones that could likely be managed in a short, one-off event. Students wanted to explore issues such as social and racial justice in schools or in specific programs or faith communities in which they currently are involved. They suggested topics such as cultural appropriation, microaggressions, gun violence, white privilege, and college student success. While it is heartening to see the many ways students sought to apply new ideas and information, the plans themselves were, by and large, not focused enough to be implemented within the time frames the students had suggested.

Our conclusion from reading the facilitated dialogue action plans was that, in addition to simply needing more time to complete such an assignment effectively, what was most valuable for students had not been strategic and concrete, but rather experiential and affective. We also noticed this emphasis on the emotional in student responses to readings such as Kay's text and an article written by white professors who teach about racism (Smith et al., 2017). When asked what the most valuable reading was, opinions on the article written by Smith and associates were mixed-in part because an academic treatment that centered the experience of white professors resonated with some but fell flat with others. However, there was the uniform praise for Kay's book. Smith et al. (2017) was presented as a typical research study published in a peer-reviewed academic journal, heavy on citations and abstract language and ideas. One student described it as "stuffy," and another remarked, "It was so heavy in research and didn't seem to get to the true meaning and challenges of teaching about racism." However, no one expressed concerns about Kay's text, which they felt embodied more useful 
techniques and personal storytelling. The preference-not in all but in many, including all of the black students-for the Kay book seemed to reflect the emotional tenor of the visit.

\section{IMPLICATIONS FOR ACTIVISM: HOLDING MULTIPLE PERSPECTIVES}

Although most students learned new information on this trip to a wounded place, the most important catalysts to action were affective rather than intellectual. Oberpfalzerová and associates' (2019) explored transitional truth-telling in Bosnia and Herzegovina, where Bosnians, Serbians, and Croatians served as "victim storytellers." As they shared their wartime experiences, their ethnic identities were shielded from listeners. When their testimonies conveyed sadness, or elicited pity or regret, the impact on listeners was the greatest. The authors concluded that victims needed to receive empathy and perpetrators needed to give empathy-and when this happened, there was reduced prejudice, reduced competitive victimhood and blaming, an increased sense of guilt for the actions perpetrated by one's in-group, a change of emotions toward the out-group, and increased interest in peace activism. Similarly, though to a lesser degree, our short trip provoked internal change in both black and white students, stretching them toward greater openness as they confronted difficult histories in Montgomery. This internal change was deeply personal and specific to each cohort member; however, participation in the cohort, and a burgeoning sense of purpose, emerged in ways that we believe will support and sustain their collaborative research.

Although many of the trust-building and group-bonding outcomes could have been achieved on any short trip, the choice of a destination with such a powerful affective heritage seems to have engendered a more profound commitment to racial justice. Student outcomes may not have coalesced yet into a single, clear plan for activism. We believe these shifts in student identity will activate their activism beyond the trip, beyond their graduate study, and well into their careers. We view these sites as uniquely suited to helping students "become critical learners and healers in a wounded space" (Battiste, Anuik \& Gillies, 2009, n.p.).

Yet it is also essential that, in sites connected to racist violence, we give time and space for students of color, in particular, to engage and retreat as needed, to ensure they feel no pressure to perform as "case studies" for white students. While emotions were high for all students, we must respect that they may be more painful and personal for some than others. One of our students, for instance, shared that she had an ancestor who had been lynched. While others have described the role of emotion work in museums (Alderman et al., 2020; Munro, 2014), our results suggest the need to consider the intra-group emotional dynamics that also influence visitors' emotional engagement with and identity work within such sites.

Our experience also shows the need to engage critically with museums and memorials. For instance, our students' calls for the "true history" of slavery to be taught takes at face value the interpretation provided at the sites in Montgomery. One black female student problematized the Legacy Museum's emphasis on male victims, as she observed that relatively few black women were represented at a site that focused largely on lynching and mass incarceration. Though women's stories are not missing from the site, they are considerably fewer than men's. An analysis of what was included or excluded, or in what ways and to what extent something was included, would help future activists consider what frames they apply to "true history." We also could do more to draw students' attention to the ways that these recently opened sites reflect presentday rather than commemorative concerns (Alderman et al., 2020). The Equal Justice Initiative has launched projects in Montgomery at an impressive scale and magnitude, but their popularity has overshadowed other sites in the city devoted to racial justice, such as the Dexter Avenue Baptist Church and the modest Freedom Riders Museum, both of which represent older, sanctified sites. How does one place-based opportunity to engage in remembrance veil or erase other forms of anti-racist memory? Addressing these critical questions will help us deepen our students' engagement, supporting them as they thoughtfully choose and frame their activism.

\section{PULLING IT ALL TOGETHER}

If we assume that history, especially American history, is always (and always has been) dealing with difference-its confrontation, management, conflicts, suppression, or celebration-we can recognize that diversity is always already in the curriculum, and that our work is to understand why and how history and memory have erased that engagement. In other words, we need not necessarily seek new stories, but we need to restore the racial contexts in which major events of American history have occurred. In doing so, new stories will emerge. Similarly, if Ed.D. cohorts seek to activate activism focused (in part) on racial justice, then Vlad Glăveanu's insights will prove instructive: new stories, and new conceptions of the possible, will emerge as cohort members create a common representational space, imbued with symbolic resources, fashioned through collaboration and dialogue, engaged with eyes wide open in the risk and uncertainty of the Other (i.e., otherness, other ideas, and other views), and enlivened by wondering, that is, an ongoing process of imagining the not yet (Keenan-Lechel et al., 2019). As cohort members achieve something Glăveanu refers to as a metaposition, they are able to see and hold multiple perspectives of reality. When this happens, a third possibility - a third spaceemerges that enables positive transformation: "A third space is a communicative achievement: situated and contingent, accomplished by actual people in actual circumstances" (Burbules, 2016, p. 3). We hope that our curriculum, our high-impact practices, and our instinct to embed inquiry at heritage sites with anti-racist framings and layers of emotion will nurture a third-space outcome that activates activism and fosters heritage leadership.

\section{REFERENCES}

Alderman, D. H., Brasher, J. P., \& Dwyer III, O. J. (2020). Memorials and monuments. Pp. 39-47. in International Encyclopedia of Human Geography, 2nd edition, Volume 9

Alexander, M. (2012). The new Jim Crow: Mass incarceration in the age of colorblindness. New York: The New Press.

Askins, K. \& Swanson, K. (2019). Holding onto emotions: A call to action in academia. Emotion, Space and Society, 33, 100617.

Bales, K. (2016). Blood and earth: Modern slavery, ecocide, and the secret to saving the world. New York: Spiegal \& Grau.

Battiste, M., Anuik, J. \& Gillies, C. (2009, May). Nourishing the learning spirit: Emerging promising practices for teaching and lifelong learning. Presentation for the Canadian Society for the Study of Education 2009 Conference: Learning Spaces, Places and Connections. Carleton University, Ottawa, Ontario.

Burbules, N. C. (2016). Being critical about being critical. A response to "Toward a transformative criticality for democratic citizenship education." Democracy \& Education, 24(2), Article 7. 
Caruthers, L. (2007). The soil of silence: Deconstructing socio-cultural and historical processes that have influenced schooling for First Nations People and African Americans. American Educational History Journal, 34(2), 303-313.

Cook, M. R. (2018). Textual politics of Alabama's historical markers: Slavery, emancipation, and civil rights. Pp. 1-31 in S. D. Brunn et al. (Eds.), Handbook of the Changing World Language Map. Springer International Publishing.

Garmston, R. J. \& Wellman, B. M. (2013). Developing collaborative norms. Pp. 27-44 in The adaptive school: A sourcebook for developing collaborative groups. Norwood, MA: Christopher Gordon Publishers.

Hawken, P. (Ed.) (2017). Drawdown: The most comprehensive plan ever proposed to reverse global warming. New York: Penguin Books.

Izard, C. E. (2010). The many meanings/aspects of emotion: Definition, functions, activation, and regulation. Emotion Review, 2, 363.

Kay, M. R. (2018). Not light, but fire: How to lead meaningful race conversations in the classroom. Portland, ME: Stenhouse Publishers.

Keenan-Lechel, S. F., Henriksen, D. \& the Deep-Play Research Group. (2019). Creativity as perspective taking: An interview with Dr. Vlad Glăveanu. Tech Trends, 63, 652-658.

Kendi, I. X. (2019). How to be an antiracist. New York: One World.

Kuh, G. D. (2008). Why integration and engagement are essential to effective educational practice in the twenty-first century. Peer Review, 10(4), 2728.

Liu, E. (2017). You're more powerful than you think: A citizen's guide to making change happen. New York: PublicAffairs.

Munro, E. (2014). Doing emotion work in museums: Reconceptualizing the role of community engagement practitioners. Museum \& Society, 12(1), 4460.

Oberpfalzerová, H., Ullrich, J., \& Jeřábek, H. (2019). Unofficial storytelling as middle ground between transitional truth-telling and forgetting: A new approach to dealing with the past in postwar Bosnia and Herzegovina. International Journal of Conflict and Violence, 13, 1-20.

Palmer, P. J. (2011). Healing the heart of democracy: The courage to create a politics worthy of the human spirit. San Francisco: Jossey-Bass.

Rothstein, R. (2014, Oct). The making of Ferguson: Public policies at the root of its troubles. Washington, DC: Economic Policy Institute. (Available online: https://www.epi.org/publication/making-ferguson/).

Sibbett, L. A. (2016). Toward a transformative criticality for democratic citizenship education. Democracy \& Education, 24(2), Article 1.

Smith, L., Kashubeck-West, S., Payton, G., \& Adams, E. (2017). White professors teaching about racism: Challenges and rewards. The Counseling Psychologist, 45(5), 651-668.

Wahl, R. (2019). Learning in democracy: Deliberation and activism as forms of education. Studies in Philosophy and Education, 38, 517-536.

Wallace-Wells, D. (2019). The uninhabitable earth: Life after warming. New York: Tim Duggan Books. 